\title{
Effects of the hydraulic infrastructure on economic growth: evidence from Catalonia
}

\author{
Jaume Freire-González ${ }^{1,2} \cdot$ Ignasi Puig-Ventosa ${ }^{2}$
}

Received: 12 November 2015/Accepted: 12 March 2016/Published online: 4 April 2016

(C) Springer International Publishing Switzerland 2016

\begin{abstract}
Public infrastructure has a positive effect on labour productivity and growth. However, different types of infrastructure produce different magnitudes of effects. This article contains an analysis of the stock of hydraulic capital and investments in Catalonia and provides empirical evidence of its effect on productivity and growth. It also compares the magnitude of this effect with the magnitude of other types of public and private capital. The research shows that hydraulic capital and investments have a positive and significant effect on economic growth. However, this effect may be lower than that resulting from other forms of public or private capital.
\end{abstract}

Keywords Hydraulic infrastructure · Production functions · Productivity · Growth

\section{Introduction}

The accumulation of hydraulic capital over time has effects on business productivity and on the growth of the aggregate output of an economy in the long term. Economic theory has developed models that determine the impact of public capital on economic growth (Arrow 1970; Baier and Glomm 2001; Barro 1990; Futagami et al. 1993; Ghosh and Roy 2004; etc.). These models can be used to obtain

Jaume Freire-González

jaumefreire@hotmail.com; jaume.freire@ouce.ox.ac.uk

1 Environmental Change Institute, University of Oxford, Oxford University Centre for the Environment, South Parks Road, Oxford OX1 3QY, UK

2 ENT Environment and Management, Sant Joan, 39, 1, 08800 Vilanova i la Geltrú, Barcelona, Spain empirical evidence of the effects of different types of infrastructure-roads, railways, ports, airports and so onon the growth of the aggregate output and labour productivity in an economy (for example, Calderón and Servén 2003; Chude and Chude 2013; Demetriades and Mamuneas 2000; Esfahani and Ramirez 2003; Röller and Waverman 2001; Sanchez-Robles 1998; etc.). A survey of empirical studies using different methods can be found in Romp and de Haan (2007).

The estimation of the effects of infrastructure or capital stock on growth is based on Aschauer (1989). This seminal work analysed the impact of public infrastructure on economic growth. After it, several other studies appeared, such as Munnell's (1990) and Lynde and Richmond (1992). However, as Gupta et al. (2014) state, the elasticities reported in this first wave of papers were questioned on the grounds that they were fraught with methodological and econometric problems (Gramlich 1994). The main problems were reverse causation from productivity to public capital, and spurious correlation due to non-stationarity of the data. Bom and Ligthart (2010) used meta-regression analysis from results of previous studies, finding an average output elasticity of public capital positive and significant of 0.15 , but heterogeneous across countries.

The empirical definition of public capital differs across studies along several dimensions (Bom and Ligthart 2010). Baldwin and Dixon (2008) distinguish three categories of infrastructure assets: (1) infrastructure assets that combine with labour to produce capital or intermediate goods; (2) infrastructure capital that combines with labour to produce final goods and services; (3) infrastructure capital that combines with other forms of capital and improves their productivity. Prud'homme (2004) defines infrastructure as capital goods which are not consumed directly. In his view, they provide services only in combination with labour and 
other inputs. Regarding hydraulic capital, he distinguishes between: water supply (dams, reservoirs, pipes, treatment plants, etc.), water disposal (sewers, used water treatment plants, etc.) and irrigation (dams, canals). Another category could be added in relation to the water distribution facilities. A detailed analysis of the effects of each type of growth and productivity would help reduce uncertainty and improve the adjustment of the models, if empirical data are available.

This paper aims to provide empirical evidence of the effects of the hydraulic infrastructure on the growth of the Catalan economy. Firstly, a description of the stock of capital of the public hydraulic infrastructure in Catalonia is presented, comparing it with other types of public capital and with the rest of Spain. Then, an econometric model is specified and estimated. This model tries to estimate the effects of the stock of hydraulic capital on the growth of the aggregate output and on the productivity of the economy. This includes the estimation of aggregate production functions for the Catalan economy. Moreover, a second model estimates the effects of investment in the hydraulic infrastructure on the productivity of the Catalan economy.

\section{Structure and composition of the stock of public capital in Catalonia}

This section contains a brief analysis of the structure and composition of public capital in Catalonia, focusing on the evolution of hydraulic public capital. The BBVA Foundation and the Valencian Institute of Economic Research (IVIE) have elaborated a series of the stock of capital in Spain for economic sectors, regions and provinces for the period 1964-2011 (Mas et al. 2013). The series are disaggregated by types of public infrastructure, including the hydraulic infrastructure. These data represent an important source of information with which to perform empirical studies of productivity and growth in Spain.

The capital stock is calculated from the permanent inventory model, which uses historical series of investment and assumptions about the useful life of infrastructure assets. ${ }^{1}$ A series of public capital stock are calculated in current prices and in constant prices using 2000 as the base year. The following magnitudes are calculated ${ }^{2}$ :

- Gross capital stock: the result of the accumulation of gross fixed capital formation flows (GFCF), that is, investment minus the "retreats" that have taken place during the period. The gross capital values assets "like new".

\footnotetext{
1 The details of the methodological criteria for the preparation of the series can be found in Mas et al. (2013).

${ }^{2}$ Idem.
}

- Net capital stock: this is the market value of the assets, under the assumption that this is equal to the current value course of the future incomes that is expected to be generated. Capital assets are valued at market prices. This is the relevant variable when measuring the provisions of economies from the perspective of the value of their "wealth".

The stock of productive capital (in constant prices): this is an indicator of the quantity of services provided by the different assets. It is a quantitative concept that takes into account the loss of efficiency of the asset. This variable represents an "indicator of the volume of the capital services", which is the relevant variable in the analysis of productivity. This is because, from the perspective of the production theory, what matters is the flow of services provided by the different types of capital assets and the market value of these assets. ${ }^{3}$

Table 1 shows the relative importance of each type of capital.

In 2006, the real net capital stock in infrastructure in Catalonia was 227,240 million in 2000 euros, representing $18.18 \%$ of the net stock of infrastructure in Spain for the same year. Regarding the hydraulic infrastructure, the real net stock in Catalonia in 2006 was 5523 million in 2000 euros, representing $9.33 \%$ of the net stock in Spain for the same year. In 2006, the percentage of the population of Catalonia in relation to Spain was $15.95 \%$, the employment was $17.31 \%$ and the gross domestic product (GDP) was $19.94 \%$.

Considering the analysis by provinces, the net stock of infrastructure in each province in relation to the total net stock of Catalonia was, in 2006, $70 \%$ in Barcelona, $10 \%$ in Girona, $7 \%$ in Lleida and $13 \%$ in Tarragona. The same percentages for the stock of the hydraulic infrastructure were $49.3 \%$ in Barcelona, $11.3 \%$ in Girona, 26.3 in Lleida and $13.1 \%$ in Tarragona. The percentages of the population for the same year in relation to Catalonia were $74.4 \%$ in Barcelona, $9.6 \%$ in Girona, $5.7 \%$ in Lleida and $10.2 \%$ in Tarragona.

\section{Effects of the hydraulic infrastructure on the growth of the Catalan economy}

The dominant economic theory states that the provision of infrastructure in a region affects positively the economic growth in the aggregate output of the economy, acting as

\footnotetext{
3 There is a broad consensus that this is the relevant variable in studies of productivity, occupying a prominent place in the studies of the OECD. The pioneering contribution in this field is by Jorgenson and Griliches (1967).
} 
Table 1 Percentage and total of the net real stock of each type of infrastructure in Catalonia and Spain (year 2006)

\begin{tabular}{|c|c|c|c|c|c|c|}
\hline Infrastructure & Barcelona & Girona & Lleida & Tarragona & Catalonia & Spain \\
\hline Road infrastructure & $6.27 \%$ & $12.61 \%$ & $18.97 \%$ & $11.94 \%$ & $8.54 \%$ & $11.93 \%$ \\
\hline Public hydraulic infrastructure & $1.72 \%$ & $2.77 \%$ & $9.00 \%$ & $2.43 \%$ & $2.43 \%$ & $4.74 \%$ \\
\hline Railway infrastructure & $5.42 \%$ & $2.62 \%$ & $7.01 \%$ & $6.57 \%$ & $5.41 \%$ & $4.59 \%$ \\
\hline Airport infrastructure & $1.40 \%$ & $0.37 \%$ & $0 \%$ & $0.19 \%$ & $1.04 \%$ & $1.23 \%$ \\
\hline Port infrastructure & $1.16 \%$ & $0.47 \%$ & $0 \%$ & $2.46 \%$ & $1.18 \%$ & $1.27 \%$ \\
\hline Urban infrastructure of local authorities & $2.42 \%$ & $1.74 \%$ & $0.86 \%$ & $0.97 \%$ & $2.05 \%$ & $2.48 \%$ \\
\hline Other $^{\mathrm{a}}$ & $81.62 \%$ & $79.42 \%$ & $64.15 \%$ & $75.44 \%$ & $79.35 \%$ & $73.75 \%$ \\
\hline Total $(\%)$ & $100 \%$ & $100 \%$ & $100 \%$ & $100 \%$ & $100 \%$ & $100 \%$ \\
\hline Total $^{\mathrm{b}}$ & 158,854 & 22,533 & 16,105 & 29,747 & 227,240 & $1,250,287$ \\
\hline
\end{tabular}

Source: Mas et al. (2013)

a This category includes both public infrastructure investments not included in other categories and other private investments in infrastructure

b Millions of 2000 euros

an additional productive factor that increases the productivity of labour.

In this context, there is a distinction between private and public infrastructure. Among the latter, there is infrastructure that is considered "productive" and others considered "non-productive" (Aschauer 1989). The productive infrastructure includes transport, electricity, gas, hydraulic and so on. The non-productive infrastructure consists of schools, hospitals, public parks and so forth. It is considered that the first has an effect on the growth and productivity of an economy, while the latter does not.

The analysis of the effects of public capital on the growth and productivity in an economy has been the object of many empirical studies over the past 25 years. Most of these have been oriented to show the effects of the transport infrastructure, which in most countries is the main capital public stock (Nombela 2005), or, given the availability of data, confined to show the effects of public capital stock together, without the possibility of disaggregating it into types of public investment.

Only one empirical work has been found that specifically analysed the effects of public capital on the hydraulic infrastructure: Garcia-Milà et al. (1996). However, several studies have provided estimates for Spain and other regions regarding the effects of a set of infrastructure, including the hydraulic infrastructure. An overview of this extensive literature was provided by De la Fuente (1996), Draper and Herce (1994), Gramlich (1994) and, with particular application to the case of Spain, Álvarez et al. (2003). Some works that have made empirical estimates of the effects of public capital in Spain are the following: Argimón et al. (1994), Arslanalp et al. (2010), Avilés, Gómez and Sánchez (2001), Boscá et al. (2002), Dabán and Murgui (1997), De la Fuente and Vives (1995), Delgado and Álvarez (2000), García-Fontes and Serra (1994), Gomez-Antonio and Fingleton (2009), González-Páramo (1995), Márquez et al.
(2011), Moreno et al. (2003), Pedraja et al. (1999), Pereira and Roca-Sagales (2003) and Raymond (1989).

This section aims to determine empirically the effects of the public hydraulic infrastructure in Catalonia on the growth of the Catalan economy.

\section{Econometric model and data}

The econometric model specified to assess the impact of hydraulic infrastructure capital on the Catalan economy is presented below. This model is based on Aschauer (1989), who developed it in his seminal work on the impact of public infrastructure on economic growth.

Aschauer assumed a regional aggregate production following a Cobb-Douglas function (Cobb and Douglas 1928), in which the aggregate production of the economy is the endogenous variable, and the public capital stock, the private capital stock and the level of employment are exogenous variables:

$Y_{\mathrm{t}}=A_{\mathrm{t}} L_{\mathrm{t}}^{\alpha} K_{\mathrm{t}}^{\beta} \mathrm{Kp}_{\mathrm{t}}^{\gamma}$,

where $Y_{\mathrm{t}}$ is the total output of the economy, $A_{\mathrm{t}}$ represents the total factor productivity or the technological level, $L_{\mathrm{t}}$ is the employed population, $K_{\mathrm{t}}$ is the private capital stock and $\mathrm{Kp}_{\mathrm{t}}$ is the public capital stock of the economy.

Parameters $\alpha, \beta$ and $\gamma$ are the product elasticities of labour, private capital and public capital, respectively. These elasticities measure the percentage change in the aggregate output of the economy when there are percentage changes in employment, private capital or public capital, respectively. If the sum of these three parameters is equal to unity, there are constant returns to scale in the economy; if it is less than unity, there are decreasing returns to scale; if it is greater than unity, there are increasing returns to scale. 
To perform the analysis, we obtained data on public and private real productive capital stock at 2000 prices. This is the variable that should be used to estimate the effects on productivity according to the OECD (Mas et al. 2013) and has been widely used in such studies. ${ }^{4}$ These data are available for the provinces of Barcelona, Girona, Lleida and Tarragona, by type of capital, for the period 1964-2006, from the BBVA foundation and the IVIE (Mas et al. 2013).

We also obtained data on employment from the four provinces for the period 1977-2008 and data on the GDP for the period 1980-2006 from the National Statistics Institute of Spain (INE). Since there is not a long enough homogeneous series for the GDP, two adjustments were made. The first one was to link the series in the base year 1986 with the series in the base year 2000. This is the usual methodology adopted by organizations such as the Statistics Institute of Catalonia (IDESCAT) and the National Statistics Institute of Spain (INE). The second adjustment was to transform the series at constant prices (base year 2000) to ensure that the GDP and capital stock series are in the same monetary units.

Having both cross-sectional data from the four Catalan provinces and temporary data allowed us to perform the regression analysis with econometric panel data estimation methods, using simultaneous equations that provide estimators that are more robust than the traditional methods of estimation, using either temporary or cross-sectional data only.

\section{Estimation of regional aggregate production functions}

To estimate the model and differentiate the effects, hydraulic capital stock was added to Eq. (1), including it separately from the other infrastructure:

$Y_{t}=A_{t} L_{t}^{\alpha} K_{t}^{\beta} K h_{t}^{\delta} K p_{t}^{\gamma}$.

This model (2) was transformed to express the equation in logarithms and per worker. Thus, the model adopts a functional form that allows the contrasting, in a simple way, of the hypothesis of increasing returns to scale:

$$
\begin{aligned}
\ln \left(Y_{i t} / L_{i t}\right)= & a+(\alpha+\beta+\delta+\gamma-1) \ln L_{i t}+\beta \ln \left(K_{i t} / L_{i t}\right) \\
& +\delta \ln \left(\mathrm{Kh}_{i t} / L_{i t}\right)+\gamma \ln \left(\mathrm{Kp}_{i t} / L_{i t}\right)+u_{i t},
\end{aligned}
$$

where $Y_{i t}$ is the GDP of province $i$ in year $t$ in constant euros of the year 2000, $L_{i t}$ the number of workers in province $i$ in year $t, a$ the technology coefficient, which reflects the total factor productivity or the current state of

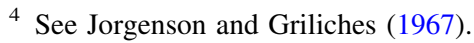

Table 2 Estimation of the aggregate production function for Catalonia adding the hydraulic capital stock

\begin{tabular}{lllll}
\hline Variables & Coefficient & Std error & $t$ statistic & Prob. \\
\hline$a$ & 4.553 & 0.152 & 29.86 & 0.0000 \\
$\alpha+\beta+\delta+\gamma-1$ & 0.065 & 0.011 & 59.97 & 0.0000 \\
$\beta$ & 0.186 & 0.014 & 12.98 & 0.0000 \\
$\delta$ & 0.053 & 0.008 & 6.70 & 0.0000 \\
$\gamma$ & 0.177 & 0.019 & 8.92 & 0.0000 \\
\hline
\end{tabular}

Weighted statistics

\begin{tabular}{llll}
\hline$R^{2}$ & 0.9997 & $\begin{array}{c}\text { Mean dependent } \\
\text { var. }\end{array}$ & 606.72 \\
Adjusted $R^{2}$ & 0.9997 & SD dependent var. & 150.28 \\
SE of regression & 1.0106 & Sum square resid. & 105.21 \\
$F$ statistic & $1.3 \times 10^{-223}$ & & \\
\hline
\end{tabular}

Dependent variable: $\ln (Y / L)$; method: GLS (cross-sectional SUR); sample: 1980-2006; included observations: 27; cross sections included: 4; total pool (balanced) observations: 108

technology, $K_{i t}$ the private capital stock of province $i$ in year $t, \mathrm{Kh}_{i t}$ the hydraulic capital stock of province $i$ in period $t, \mathrm{Kp}_{i t}$ the public capital stock in infrastructure excluding the hydraulic capital of province $i$ in year $t$ and $u_{i t}$ the error. Table 2 shows the results of estimating the model shown in Eq. (3) by the method of generalized least squares (GLS) cross section seemingly unrelated regression (SUR).

All the production factors specified in the estimated production function have a significant positive impact on the aggregate output of the economy. All the estimated parameters have the expected sign (positive), meaning that an increase in the exogenous variables leads to an increase in the endogenous variable and are significant at the confidence level of $99 \%$. The GLS method provides a very high adjusted coefficient of determination (adjusted $R^{2}$ ).

The coefficient relevant to our analysis is $\delta$, since this is the coefficient that accompanies the capital stock in the hydraulic infrastructure. The estimated value for this coefficient is 0.053 . This means that a $1 \%$ increase in the stock of the hydraulic infrastructure in Catalonia would increase the GDP by $0.053 \%$. This shows that the stock of the hydraulic infrastructure is a relevant productive factor with a positive impact on the economic growth in Catalonia. However, both the stock of private capital and the stock of other public infrastructure have a greater impact on GDP growth, adopting values of 0.18 and 0.17 , respectively. Moreover, the fact that the coefficient $\alpha+$

\footnotetext{
5 These findings are for GDP and not for GDP/L specified in the function, because a transformation was applied to the original equation (note that the explanatory variable is also $\mathrm{Kh} / \mathrm{L}$ ).
} 
$\beta+\delta+\gamma-1$ is positive indicates that there are increasing returns to scale. This model shows the long-term effects.

To verify the existence of unit roots and therefore to evaluate the cointegration of the series and distinguish between the effects in the short and the long term, another transformation was made to convert this model into an error correction mechanism model (ECM). This is the highest generalization of a dynamic model:

$$
\begin{aligned}
\Delta \ln \left(Y_{i t} / L_{i t}\right)= & (\alpha+\beta+\delta+\gamma-1) \Delta \ln L_{i t}+\beta \Delta \ln \left(K_{i t} / L_{i t}\right) \\
& +\delta \Delta \ln \left(\mathrm{Kh}_{i t} / L_{i t}\right)+\gamma \Delta \ln \left(\mathrm{Kp}_{i t} / L_{i t}\right) \\
& +\theta \Delta \ln \left(Y_{i t-1} / L_{i t-1}\right)+\tau u_{i t-1}+\varepsilon_{i t}
\end{aligned}
$$

where the symbol $\Delta$ represents variables in differences and $u_{i t-1}$ represents the error term delayed by one period, resulting from the estimates in Table 2. This model (4) was also estimated by GLS cross-sectional SUR. The results are shown in Table 3.

In this case, the estimated coefficients are not significant at the $95 \%$ confidence level, except for the coefficient that accompanies the error term of the previous estimation delayed by one period $(\tau)$, although the hydraulic capital coefficient $(\delta)$ is significant at the $90 \%$ confidence level. The estimated parameters in Table 2 are the long-term effects, while Table 3 shows the short-term effects.

The low level of significance of the parameters could indicate that the capital stock has no significant effects in the short term on the aggregate output in the economy. Despite the parameter $\alpha+\beta+\delta+\gamma-1$ having a low

\begin{tabular}{|c|c|c|c|c|}
\hline Variables & Coefficient & Std error & $t$ statistic & Prob. \\
\hline$\alpha+\beta+\delta+\gamma-1$ & -0.042 & 0.099 & -0.42 & 0.6743 \\
\hline$\beta$ & 0.136 & 0.112 & 1.21 & 0.2263 \\
\hline$\delta$ & 0.218 & 0.134 & 1.63 & 0.1058 \\
\hline$\gamma$ & 0.173 & 0.154 & 1.12 & 0.2632 \\
\hline$\theta$ & 0.027 & 0.080 & 0.34 & 0.7310 \\
\hline$\tau$ & -0.233 & 0.070 & -3.33 & 0.0012 \\
\hline \multicolumn{5}{|l|}{ Weighted statistics } \\
\hline$R^{2}$ & 0.4609 & \multicolumn{2}{|c|}{$\begin{array}{l}\text { Mean dependent } \\
\text { var. }\end{array}$} & 0.2565 \\
\hline Adjusted $R^{2}$ & 0.4322 & \multicolumn{2}{|c|}{ SD dependent var. } & 1.3539 \\
\hline $\begin{array}{l}\mathrm{SE} \text { of } \\
\text { regression }\end{array}$ & 1.0202 & \multirow{2}{*}{\multicolumn{2}{|c|}{ Sum square resid. }} & 97.839 \\
\hline$F$ statistic & \multicolumn{2}{|l|}{$2.00 \times 10^{-11}$} & & \\
\hline
\end{tabular}

Table 3 Estimation of the ECM model of an aggregate production function in Catalonia adding the hydraulic capital stock

Dependent variable: $\Delta \ln (Y / L)$; method: GLS (cross-sectional SUR); sample: 1982-2006; included observations: 25; cross sections included: 4; total pool (balanced) observations: 100 level of significance, the fact that it has a negative sign indicates, unlike the estimates in Table 2, the possibility of decreasing returns to scale in the short term. ${ }^{6}$

One of the main criticisms of growth models based on the estimation of aggregate production functions, apart from the implicit assumptions of substitutability between factors, is the possible existence of endogeneity between the explanatory variables and the error term. This is mainly because the growth of the capital stock affects the output growth, but at the same time, the output growth affects the growth of the capital stock. This problem can be solved by analysing the cointegration between variables. The high level of significance (99\% confidence) of the coefficient $\tau$ that accompanies the error term of the previous estimate delayed by a period, also called the error correction term, implies that the series are cointegrated and therefore there is no endogeneity bias.

\section{Effects of investments in the hydraulic infrastructure on the labour productivity in Catalonia}

To obtain more empirical evidence and compare the results of the estimates in the previous section, an analysis of labour productivity was performed on the investments in infrastructure, as proposed by Nombela (2005).

In this case, an estimate of the effects on labour productivity caused by investment in the hydraulic infrastructure in the Catalan economy will be developed, based on the data used in the previous sections. The investments considered will be those made in the previous periods. Using these investments avoids the possible endogeneity problem between economic growth and investment in infrastructure, because the current economic growth cannot affect the investments in previous periods. This exercise, in addition to the estimates of aggregate production functions performed in the previous section, can be useful because infrastructure requires some years after the investment is accounted in the statistics for it to be put into operation and fully used, thus improving the productivity of the economy.

The specified model to estimate is shown below:

$$
\begin{aligned}
\ln \left(\mathrm{VAB}_{i t / L_{i t}}\right)= & \alpha+\mu \ln \left(\operatorname{InKh}_{i t-Q}\right)+\beta \ln \left(\operatorname{InKp}_{i t-Q}\right) \\
& +\varphi \ln \left(\operatorname{In} K_{i t-Q}\right)+u_{i t}
\end{aligned}
$$

where $\mathrm{VAB}_{i t}$ is the gross value added of province $i$ and year $t ; L_{i t}$ is the number of workers in province $i$ and year $t$;

\footnotetext{
${ }^{6}$ Decreasing returns to scale occur when an increase occurs in all the production factors of the same proportion, leading to an increase in the total production of a smaller proportion, while increasing returns occur when there is an increase in the production of a higher proportion.
} 
Table 4 Estimates of the effects of investments in the hydraulic infrastructure on the labour productivity in Catalonia

\begin{tabular}{lclcc}
\hline Variables & Coefficient & Std error & $t$ statistic & Prob. \\
\hline$\alpha$ & 8.672 & 0.066 & 131.0 & 0.0000 \\
$\mu$ & 0.053 & 0.008 & 6.175 & 0.0000 \\
$\beta$ & 0.012 & 0.034 & 0.358 & 0.7206 \\
$\varphi$ & -0.016 & 0.030 & -0.549 & 0.5844 \\
\hline
\end{tabular}

Weighted statistics

\begin{tabular}{lllc}
\hline$R^{2}$ & 0.9999 & $\begin{array}{c}\text { Mean dependent } \\
\text { var. }\end{array}$ & 63.937 \\
Adjusted $R^{2}$ & 0.9999 & SD dependent var. & 187.79 \\
$\begin{array}{l}\text { SE of } \\
\text { regression }\end{array}$ & 1.00399 & Sum square resid. & 80.639 \\
$F$ statistic & $2.9 \times 10^{-182}$ & & \\
\end{tabular}

Dependent variable: $\ln (\mathrm{VAB} / L)$ method: GLS (cross-sectional SUR); sample (adjusted): 1986-2006; included observations: 21; cross sections included: 4; total pool (balanced) observations: 84

$\operatorname{Inkh}_{i t-Q}$ is the average of investments in the hydraulic infrastructure of the 5 years prior to year $t$ in province $i$; Inkp $_{i t-Q}$ is the average of investments in other public infrastructure in the 5 years prior to year $t$ in province $i$; Ink $_{i t-Q}$ is the average of private sector investments in the 5 years prior to year $t$ in province $i$; and $u_{i t}$ is the error term.

Similarly to the previous section, the hypothesis that the elasticity is positive is verified. A measure of the effects of the hydraulic infrastructure on the labour productivity in Catalonia is also provided.

Table 4 shows the estimates of Eq. (5) using panel data by the method of GLS cross-sectional SUR.

There is a positive and significant effect of investments in the hydraulic infrastructure on the labour productivity in Catalonia. This coefficient $\mu$ has the same value of elasticity as the estimates made from the productive capital, that is, 0.053 , which reinforces the results. The other coefficients differ in their estimated value and sign, but they are not significant. The high value of $R^{2}$ could indicate statistical problems.

Table 5 shows the estimation of the same model for GLS cross-sectional weights (6), but with specific coefficients for investments in the hydraulic infrastructure in each province:

$$
\begin{aligned}
\ln \left(\mathrm{VAB}_{\left.i t / L_{i t}\right)=}\right) & \alpha \beta \ln \left(\operatorname{InKp}_{\text {it-Q }}\right)+\varphi \ln \left(\operatorname{InK}_{i t-Q}\right) \\
& +\mu_{1} \ln \left(\operatorname{InKh}_{\text {Barcelona } t-Q}\right) \\
& +\mu_{2} \ln \left(\operatorname{InKh}_{\text {Lleida } t-Q}\right) \\
& +\mu_{3} \ln \left(\operatorname{InKh}_{\text {Girona } \_-Q}\right) \\
& +\mu_{4} \ln \left(\operatorname{InKh}_{\text {Tarragona } \_t-Q}\right)+u_{i t}
\end{aligned}
$$

Table 5 Estimate of the effects of investments on labour productivity in Catalonia with individual effects for the hydraulic infrastructure

\begin{tabular}{lclcc}
\hline Variables & Coefficient & Std error & $t$ statistic & Prob. \\
\hline$\alpha$ & 7.680 & 0.220 & 34.78 & 0.0000 \\
$\beta$ & 0.087 & 0.039 & 2.223 & 0.0291 \\
$\varphi$ & -0.020 & 0.027 & -0.781 & 0.4369 \\
$\mu_{1}$ & 0.041 & 0.019 & 2.204 & 0.0305 \\
$\mu_{2}$ & 0.056 & 0.017 & 3.362 & 0.0012 \\
$\mu_{3}$ & 0.050 & 0.019 & 2.683 & 0.0089 \\
$\mu_{4}$ & 0.062 & 0.019 & 3.336 & 0.0013 \\
\hline
\end{tabular}

Weighted statistics

\begin{tabular}{llll}
\hline$R^{2}$ & 0.9997 & $\begin{array}{c}\text { Mean dependent } \\
\text { var. }\end{array}$ & 9.8573 \\
Adjusted $R^{2}$ & 0.9996 & SD dependent var. & 2.5185 \\
SE of regression & 0.0440 & Sum square resid. & 0.1493 \\
$F$ statistic & $2.2 \times 10^{-134}$ & & \\
\hline
\end{tabular}

Dependent variable: $\ln (\mathrm{VAB} / L)$; method: MQG (cross-sectional weights); sample: 1986-2006; included observations: 21; cross sections included: 4; total pool (balanced) observations: 84

This estimate, unlike the previous ones, allows us to see the effects of the infrastructure investments made in each province on the labour productivity in the same province. The individual coefficients for each province are significant in all cases. The estimated elasticities are 0.042 for Barcelona, 0.057 for Lleida, 0.050 for Girona and 0.063 for Tarragona. Accordingly, the hydraulic investments in the provinces of Tarragona and Lleida have a slightly higher impact on productivity than those made in Girona or Barcelona.

When specifying the individual effects, that is, a coefficient for each province, investments in other public infrastructure gain significance but provide an estimated coefficient that is significantly lower than the estimates of productive capital stock of 0.087 ( $\beta$ coefficient) compared with 0.18 from the estimates in Table 2.

\section{Conclusions}

The aim of this paper was to provide empirical evidence of the impact of the hydraulic infrastructure on the economic growth in Catalonia. One of the main results is that the elasticity of the current stock of the hydraulic infrastructure in Catalonia is 0.053 , meaning that an increase of $1 \%$ in the current stock of the hydraulic infrastructure in Catalonia entails an increase of $0.053 \%$ in the economic output in the long term. Other public and private capital elasticities are higher, 0.17 and 0.18 , respectively. 
The short-term effects, based on the estimation of an ECM model, ${ }^{7}$ are not significant, which could indicate that the hydraulic capital stock does not affect the growth in output in the short term, but nor do other public and private capital stocks.

Analysing the effects of investments in the hydraulic infrastructure on productivity in the Catalan economy, we found estimated elasticities for some investments in Catalonia (the same value of 0.053 was obtained). The elasticities in each province are 0.063 for Tarragona, 0.057 for Lleida, 0.050 for Girona and 0.042 for Barcelona; therefore, investments in the hydraulic infrastructure in Tarragona and Lleida have a higher effect on the aggregate labour productivity of the Catalan economy.

These results are consistent with the empirical literature on estimates of the effects of public capital and hydraulic capital on economic growth. Garcia-Milà et al. (1996) obtained an elasticity of 0.069 for hydraulic capital for the US.

Additionally, several studies ${ }^{8}$ have shown that when extending the geographical scope of the analysis, the estimated elasticities are higher, since there are spillover effects. That is, the provision of infrastructure in a region affects the growth of the output of the adjacent regions, so the effect of the hydraulic infrastructure in Catalonia may have effects on the growth of the output in other regions of Spain, especially those that are geographically closer, and vice versa. Further research should analyse and quantify these effects, considering the basin level when relevant, and when specific data are available.

Acknowledgments We would like to acknowledge the Catalan Water Agency (ACA) for funding the original project from which this research article derives. We would also like to thank the useful comments received from the peer reviewers.

\section{References}

Álvarez A, Orea L, Fernández J (2003) La productividad de las infraestructuras en España. Papeles de Economía Española 95:125-136

Argimón I, González-Páramo JM, Martín MJ, Roldán JM (1994) Productividad e infraestructuras en la economía española. Moneda y Crédito 198:207-241

Arrow KJ (1970) Public investment, the rate of return and optimal fiscal policy. The Johns Hopkins University Press, Baltimore

Arslanalp S, Bornhorst F, Gupta S, Sze E (2010) Public capital and growth. IMF Working Paper. WP/10/175

Aschauer DA (1989) Is public expenditure productive? J Monet Econ 23:177-200

Avilés A, Gómez R, Sánchez J (2001) The effects of public infrastructure on the cost structure of Spanish industries. Span Econ Rev 3(2):131-150

\footnotetext{
7 The estimation of this model was also used to contrast the cointegration of the series.

${ }^{8}$ For example, Nombela (2005).
}

Baier SL, Glomm G (2001) Long-run growth and welfare effects of public policies with distortionary taxation. J Econ Dyn Control 25:2007-2042

Baldwin JR, Dixon J (2008) Infrastructure capital: what is it? Where is it? How much of it is there? Research Paper Research Paper Series, 16

Barro RJ (1990) Government spending in a simple model of exogenous growth. J Polit Econ 98:103-125

Bom P, Ligthart JE (2010) What have we learned from three decades of research on the productivity of public capital? CESifo working paper series No. 2206, Center discussion paper no. 2008-10

Boscá JE, Escribá J, Murgui MJ (2002) The effect of public infrastructure on the private productive sector of Spanish regions. J Reg Sci 42(2):301-326

Calderón C, Servén L (2003) The output cost of Latin America's infrastructure gap. In: Easterly W, Servén L (eds) The limits of stabilization: infrastructure, public deficits, and growth in Latin America. Stanford University Press, Palo Alto, pp 95-118

Chude NP, Chude DI (2013) Impact of government expenditure on economic growth in Nigeria. Int J Bus Manag Rev 1(4):64-71

Cobb CW, Douglas PH (1928) A theory of production. Am Econ Rev 18(supplement):139-165

Dabán T, Murgui MJ (1997) Convergencia y rendimientos a escala en las regiones españolas: La base de datos BD.MORES. Información Comercial Española 762:66-86

De La Fuente A (1996) Infraestructuras y productividad: un panorama de la evidencia empírica. Información Comercial Española 757:25-40

De La Fuente A, Vives X (1995) Infrastructure and education as instruments of regional policy: evidence from Spain. Econ Policy 20:11-54

Delgado MJ, Álvarez I (2000) Las infraestructuras productivas en España: estimación del stock en unidades físicas y análisis de su impacto en la producción privada regional. Revista Asturiana de Economía 19:155-180

Demetriades P, Mamuneas T (2000) Intertemporal output and employment effects of public infrastructure capital: evidence from 12 OECD economies. Econ J 110:687-712

Draper M, Herce JA (1994) Infraestructuras y crecimiento: un panorama. Revista de Economía Aplicada 6:129-168

Esfahani H, Ramirez M (2003) Institutions, infrastructure and economic growth. J Dev Econ 70(2):443-477

Futagami K, Morita Y, Shibata A (1993) Dynamic analysis of an endogenous growth model with public capital. Scand J Econ 95:607-625

García-Fontes W, Serra D (1994) Capital público, infraestructuras y crecimiento. In: Esteban JM, Vives X (eds) Crecimiento y convergencia regional en España y Europa 2:451-478. Instituto de Análisis Económico

Garcia-Milà T, McGuire TJ, Porter RH (1996) The effect of public capital in state-level production functions reconsidered. Rev Econ Stat 78(1):177-180

Ghosh S, Roy U (2004) Fiscal policy, long-run growth, and welfare in a stock-flow model of public goods. Can J Econ 37(3):742-756

Gomez-Antonio M, Fingleton B (2009) Analysing the impact of public capital stock using the NEG Wage equation: a panel data approach. SERC Discussion Paper 24

González-Páramo JM (1995) Infraestructuras, productividad y bienestar. Investigaciones Económicas 19(1):155-168

Gramlich EM (1994) Infrastructure investment: a review essay. J Econ Lit 32:1176-1196

Gupta S, Kangur A, Papageorgiou C, Wane A (2014) Efficiencyadjusted public capital and growth. World Dev 57:164-178

Jorgenson DW, Griliches Z (1967) The explanation of productivity change. Rev Econ Stud 34:249-280 
Lynde C, Richmond J (1992) The role of public capital in production. Rev Econ Stat 74:37-44

Márquez MA, Ramajo J, Hewings GJD (2011) Public capital and regional economic growth: a SVAR approach for the Spanish regions. Investig Reg 21:199-223

Mas M, Pérez F, Uriel E (2013) El stock y los servicios del capital en España (1964-2011): Evolución y perspectivas del patrón de acumulación. Fundación BBVA, Bilbao

Moreno R, López-Bazo E, Artís M (2003) On the effectiveness of private and public capital. Appl Econ 35:727-740

Munnell AH (1990) Why has productivity growth declined? Productivity and public investment. N Engl Econ Rev:3-22

Nombela G (2005) Infraestructuras de transporte y productividad. Presupuesto y gasto público 39:191-215

Pedraja F, Ramajo J, Salinas J (1999) Eficiencia productiva del sector industrial español: un análisis espacial y sectorial. Papeles de Economía Española 80:51-67
Pereira AM, Roca-Sagales O (2003) Spillover effects of public capital formation: evidence from the Spanish regions. J Urban Econ $53: 238-256$

Prud'homme R (2004) Infrastructure and development. Lessons of experience. In: Proceedings of the 2004. Annual Bank conference on Development Economics, pp 153-181

Raymond JL (1989) Productividad de los factores y expansión del sector público en España. Papeles de Economía Española 41:159-171

Röller LH, Waverman L (2001) Telecommunications infrastructure and economic development: a simultaneous approach. Am Econ Rev 91:909-923

Romp W, de Haan J (2007) Public capital and economic growth: a critical survey. Perspektiven der Wirtschaftspolitik 8(s1):6-52

Sanchez-Robles B (1998) Infrastructure investment and growth: some empirical evidence. Contemp Econ Policy 16:98-108 